\title{
Risk Factors in a Logistics Company Using Renewable Energy Sources
}

\author{
Julia Giera * and Ewa Kulińska \\ Faculty of Production Engineering and Logistics, Opole University of Technology, 45-758 Opole, Poland; \\ e.kulinska@po.edu.pl \\ * Correspondence: j.giera@po.edu.pl
}

\section{check for}

updates

Citation: Giera, J.; Kulińska, E. Risk Factors in a Logistics Company Using Renewable Energy Sources. Energies 2021, 14, 8152. https://doi.org/ $10.3390 /$ en 14238152

Academic Editor: Elżbieta Szymańska

Received: 26 September 2021

Accepted: 1 December 2021

Published: 5 December 2021

Publisher's Note: MDPI stays neutral with regard to jurisdictional claims in published maps and institutional affiliations.

Copyright: (c) 2021 by the authors. Licensee MDPI, Basel, Switzerland. This article is an open access article distributed under the terms and conditions of the Creative Commons Attribution (CC BY) license (https:// creativecommons.org/licenses/by/ $4.0 /)$.

\begin{abstract}
Investment in renewable energy sources by logistics companies has become commonplace. Organizations decide to invest in renewable energy sources not only for economic or environmental reasons, but because it is also prestigious for them. The aim of this article is to present the possible risk factors for a logistics company that uses or wants to implement renewable energy sources. This study identified individual risk factors and control mechanisms to reduce the likelihood of a particular risk factor occurring. In this article, the research methodology used is risk management through implementing a diagram of the risk-related decision-making processes of logistics companies around renewable energy sources. The analysis of the risk factors of renewable energy sources is an important element in assessing their effectiveness. By implementing the procedure of selecting an appropriate renewable energy source by logistic entities and implementing an element of risk management, there will be a significant positive impact on the optimal selection of a renewable energy source by enterprises.
\end{abstract}

Keywords: renewable energy sources; enterprises; economic assessment; investments

\section{Introduction}

Humans are the main elements shaping their surroundings, including the environment. Humans are often willing to use available resources, which, although unknowingly, destructively affects nature. Over the years, the level of negative environmental impact had by humans has become significant. It has become necessary to look for an alternative to non-renewable resources. In this context, the economic and ecological zone has turned into a contradiction [1,2], and, at the moment, the sustainable development of both areas is being pursued. Minimizing the negative impact on the natural environment by logistics companies is as important an element for organizations as constant development. Investing in renewable energy sources is a long-term process. Therefore, the selection of a renewable energy source is of fundamental importance in order to maximize the potential of renewable energy. The negative effects of climate change continue to worsen. There is an increase in temperatures, as well as the severity and frequency of natural disasters [3]. This element not only affects ecology, but also causes economic losses. Therefore, there is a need to manage risk in terms of ecology and economy, including logistics $[4,5]$.

At present, the main problem is the systematic decline of the number of non-renewable resources and the pollution of the natural environment. Modern technologies' transforming energies degrade the natural environment, where the energy generated from coal and oil has the most negative impact. Due to the subsequent irreversible climate change, an alternative element is sustainable development, where renewable energy sources are used [6,7]. Logistics companies decide to invest in renewable energy sources not only for economic or environmental reasons, but also because it is prestigious for the organization. Choosing the most effective source of renewable energy for a given entity is a key element.

The aim of this article is to present risk factors for a logistics company using renewable energy sources. The research identified individual risk factors in the following types of re- 
newable energy: solar, biomass, and wind energy. Methods of counteracting the occurrence of a given risk factor in a logistics company, while protecting the natural environment, were indicated. In the article, the research methodology used is risk management through implementing a diagram of the risk-related decision-making processes of logistics companies around renewable energy sources. The decision to select a given type of renewable energy source requires the detailed identification and analysis of possible risk factors. Proper risk management should start at the stage of investment in an unconventional energy source and then be cyclically carried out during the use of a given energy source. Investments by logistics entities in renewable energy sources are initially high financial investments but should, after some time, bring financial benefits to the entities. The most important element, however, is to maintain the continuity of logistics activities performed by a given entity, where the key element is to prevent the lack of access to energy. Implementing the procedure of selecting an appropriate source of renewable energy, with the simultaneous management of risk factors, significantly influences the coordination of the effective and pro-ecological development of the company.

\section{Renewable Energy Sources}

The development of renewable energy sources (RES) is one of the fastest growing sectors of the economy in the world market. The intensity of the development of unconventional energy sources stimulates transport, construction, energy production, and storage $[8,9]$.

Energy from renewable sources include water energy, solar radiation, wind, and earth energy, which includes biomass and geothermal energy. Investments in renewable energy sources by enterprises and natural persons result in measurable environmental, energy, and financial effects. The constant increase in the number of available renewable energies has had a measurable effect in reducing energy resources, improving the condition of the natural environment and organic emissions of pollutants into the atmosphere and waters, and reducing the amount of generated waste, the disposal of which is impossible [10,11].

Environmental investments in the RES market have both positive and negative features. Elements conducive to development in renewable energy sources include [8,12]:

- steadily rising commercial energy prices,

- free availability of products for obtaining renewable energy,

- functionality of solutions,

- availability of sources of financing from the state and private budgets, and

- environmental awareness in society.

The main elements reducing investment in renewable energy sources are [8]:

- a lack of financial support for investors,

- high prices of products necessary to obtain electricity,

- a lack of legal and financial facilitations, and

- a long payback period.

Each country has a certain specific RES potential that cannot be compared. Each state and economic entity has limited possibilities in terms of selecting an appropriate source of renewable energy. These are the criteria $[13,14]$ :

- technical aspects,

- economic,

- market,

- latitude,

- access to the sea/ocean,

- number of watercourses, and

- the share of agricultural crops and forests in the total area.

Logistics companies most often invest in the following renewable energy sources: solar energy, biomass energy, water energy, and wind energy. Table 1 characterizes the basic sources of renewable energy. The type of investment and operation are also specified. 
Table 1. Characteristics of renewable energy sources.

\section{Type of Renewable Energy}

\section{Characteristic}

Solar energy can be transformed into electricity and heat. It is used in heat engineering (thermal solar collectors) and power engineering (photovoltaic cells). Solar collectors convert solar radiation into thermal energy. Photovoltaic cells are used in the direct conversion of solar radiation to electricity. A photovoltaic cell converts solar radiation directly into electricity. It does not adversely affect the environment as there is no by-product of pollution and noise. It shows the least negative impact on the environment.

Characteristics of investment and operation

Problem with storing and using the produced energy at the right time.

High cost of enabling devices for conversions.

Installing solar panels mainly on roofs. It is possible to mount them on the walls, southern buildings or the ground.

Characteristic

Biomass is the oldest renewable energy source. These are organic plant products, e.g., wood and plant waste (straw and municipal waste). The term 'biomass' also includes refined wood fuel. It is mainly wood briquettes and pallets.

Characteristics of investment and operation

Biomass energy

The energy contained in biomass can be processed into other, very convenient forms of biofuels.

Plant biomass obtained during changing weather conditions usually has increased humidity and requires additional drying. The drying process of biomass is carried out before its storage in order to eliminate the water contained in the material.

A commonly used method of mechanical processing of biomass is its comminution (cutting, chipping) and pressing, briquetting, or pelleting.

Characteristic

Mechanical energy flowing from water is used in renewable energy sources and, more precisely, in water energy. Energy conversion is used to obtain electricity (hydropower) or to drive machines, i.e., for turbines or water wheels.

The energy of water is broken down into different energies:

- river flow (kinetic energy is converted into electricity),

- the mechanical energy of the oceans (movements of water mass caused by tides, waves, or differences in density).

Water energy

Characteristics of investment and operation

The energy of this method is only used near water. Limited localization of water energy use.

Very high investment and operating costs. The highest source of renewable energy mentioned in this work.

The amount of potential energy depends on the height of the water drop. Fluctuations in the intensity of energy produced

Characteristic

The energy of wind and electricity production is generated in modern wind farms. It enables obtaining energetically useful energy. The principle of operation is the conversion of the kinetic energy of the wind into mechanical energy, which is then converted into electricity.

Characteristics of the investment and operation

Wind energy

The wind used is an everyday phenomenon, this one a kind of "natural resource" will never be exhausted.

The investment is very expensive. The costs of its installation are reimbursed depending on the power of the plant, after 5 to 25 years.

The windmills generate noise. They also force the installation of power plants away from buildings. 
The document of national law regulating issues in the energy sector is the "Energy Law". The Act specifies [22]:

- $\quad$ principles of shaping the state's energy policy,

- $\quad$ rules and conditions for the supply and use of fuels and energy, and

- $\quad$ principles of operation of energy enterprises and authorities competent in matters of fuel and energy management.

\section{The Risk of Green Logistics Companies}

More and more entrepreneurs are investing in renewable energy sources, becoming so-called green jobs. By giving up or limiting the acquisition of electricity in a conventional manner. The implementation of the sustainable development of enterprises concerns processes related to the production, use, and recycling of devices using renewable energy sources [8].

Preserving the natural environment should be a priority for logistics companies, while at the same time the continue to develop the organization. It requires meeting appropriate standards and environmental obligations, including the use of renewable energy sources and creating clean production technologies [10].

The constantly decreasing number of natural resources makes entrepreneurs realize that investing in renewable energy sources must be a long-term process. Therefore, the activities performed are aimed at the further development of the organization without increased consumption of natural resources.

The concept of sustainable development requires enterprises to implement the concept of corporate social responsibility in an attempt to increase their competitive advantage by $[8,23]$ :

- broadening social competences,

- having a higher innovation index,

- $\quad$ improving the environment in which the organization operates, and

- $\quad$ identification of potential risk areas and selection of the priority sphere.

The concept of risk can be defined as the possibility of an event that will affect the achievement of the organization's goals. It has a measurable effect and probability. Enterprises perceive risk factors as a negative element [24]. The knowledge of the possible occurrence of risk factors constitutes the basis for commencing actions aimed at counteracting the occurrence of the negative effects of disturbances.

Risk management should be deliberate and planned. Therefore, a key element is the development by the entity of control mechanisms aimed at counteracting the occurrence of disturbances. It is also important to take a comprehensive look at the organization and the prevention of risk factors not only in a given process, but in all processes occurring in the organization.

Risk management is compliance with the formula of the entity's management effectiveness, extended by the management stage. The aim of risk management is to optimize the benefits resulting from the reduction of risk factors and the reduction of possible losses. In order to effectively manage risk, it is necessary to know the sources of risk factors and what disruptions affect their occurrence [24].

There are four main groups of risk factors that affect companies' investing in renewable energy [25,26], they are:

- political and legal risk,

- technical risk,

- economic risk, and

- social risk.

Making the decision to invest in renewable energy sources requires risk factor analysis to be conducted. Proper risk management, leading to the achievement of the assumed goals, should start at the stage of planning a given investment and using devices for obtaining renewable energy [25]. 


\section{Risk Factors Using Renewable Energy Sources in the Enterprise}

After characterizing renewable energy sources that can be used in logistics facilities, the three most commonly used renewable energy sources were analyzed for further research:

- Solar energy,

- Biomass energy,

- Wind energy.

In terms of logistics companies, the following were distinguished: transport, production, and warehouse companies. A characteristic feature of these organizations is high energy demand, and they play a key role in the supply chain. Therefore, the analysis of renewable energy sources is based on the key links of the supply chain.

Risk factors were distinguished, characterizing a specific source of renewable energy by assigning it to a given type of logistics company. A group of risk factors that can occur in any logistics company has also been defined. Table 2 shows the risk factors that may occur in logistics companies that invest in and use renewable energy sources.

Table 2. Risk factors of a logistics company using renewable energy sources.

\begin{tabular}{|c|c|c|c|}
\hline Type of Renewable Energy & Type of Logistics Company & Risk Factors & Control Mechanism \\
\hline \multirow{14}{*}{ Solar energy } & \multirow{5}{*}{$\begin{array}{l}\text { Transport company-electric } \\
\text { energy of vehicles }\end{array}$} & $\begin{array}{l}\text { Incorrect display of information about } \\
\text { the battery percentage in the vehicle. }\end{array}$ & $\begin{array}{l}\text { Data standardization for vehicle users, } \\
\text { suppliers, and consumers. }\end{array}$ \\
\hline & & Uncontrolled breakdown of the battery. & $\begin{array}{l}\text { Systematic battery control and repair. } \\
\text { Improving the efficiency of } \\
\text { battery function. }\end{array}$ \\
\hline & & $\begin{array}{l}\text { Incorrect calculation of the amount of } \\
\text { energy needed to transport the goods. }\end{array}$ & $\begin{array}{l}\text { Electric vehicles have the ability to } \\
\text { store energy. } \\
\text { Intelligent vehicle charging systems. } \\
\text { Identification of the vehicle's charging } \\
\text { station according to the route to be } \\
\text { traveled by the driver. }\end{array}$ \\
\hline & & $\begin{array}{l}\text { Vehicle weight too high. Possibility of } \\
\text { overloading the vehicle axle after } \\
\text { loading the goods into the trolley. }\end{array}$ & $\begin{array}{l}\text { Elements reducing the weight of the } \\
\text { vehicle parts. } \\
\text { The use of devices that determine the } \\
\text { correct distribution of goods in the trailer. }\end{array}$ \\
\hline & & $\begin{array}{l}\text { The risk of the driver having to change } \\
\text { routes. There is not enough energy in } \\
\text { the vehicle to complete the journey. }\end{array}$ & $\begin{array}{l}\text { Electric vehicles' access management } \\
\text { plans are required to implement access } \\
\text { management plans for the electric } \\
\text { vehicle charging infrastructure. } \\
\text { Creation of a two-way flow of } \\
\text { electricity; a "vehicle-grid". }\end{array}$ \\
\hline & Manufacturing company & $\begin{array}{l}\text { Risk of insufficient solar energy } \\
\text { being supplied. Dependence on } \\
\text { weather conditions. }\end{array}$ & $\begin{array}{l}\text { Providing consumers with incentives } \\
\text { to reduce their energy consumption at } \\
\text { peak loads and use them in periods } \\
\text { where the amount of energy produced } \\
\text { is lower than demand. }\end{array}$ \\
\hline & \multirow[t]{2}{*}{ Warehouse company } & $\begin{array}{l}\text { Uncontrolled temperature changes } \\
\text { in refrigerated warehouses. Risk of } \\
\text { destroying stored goods. Belts can } \\
\text { become deformed and lose their } \\
\text { properties after uncontrolled } \\
\text { temperature rises and falls. }\end{array}$ & $\begin{array}{l}\text { Conventional energy supply support. } \\
\text { Energy storage. Temperature } \\
\text { control sensors. }\end{array}$ \\
\hline & & $\begin{array}{l}\text { Incorrect use of applications providing } \\
\text { information about delivered } \\
\text { energy deposits. }\end{array}$ & $\begin{array}{l}\text { Energy storage. Creation of mobile } \\
\text { energy storage for electric vehicles. }\end{array}$ \\
\hline & \multirow{6}{*}{ Logistics company } & \multicolumn{2}{|c|}{ Risk factors that may occur in any logistics company } \\
\hline & & \multicolumn{2}{|l|}{$\begin{array}{l}\text { High failure rate of parts. } \\
\text { Mechanical parts used in solar panels. }\end{array}$} \\
\hline & & \multicolumn{2}{|c|}{ Risk of contamination and corrosion of the device. } \\
\hline & & \multicolumn{2}{|c|}{ The risk of low efficiency of solar energy use, due to the lack of constant supervision. } \\
\hline & & \multicolumn{2}{|c|}{ Risk of high unreliability of some system components. } \\
\hline & & \multicolumn{2}{|c|}{ Risk of unstable government policy of financial support. } \\
\hline
\end{tabular}


Table 2. Cont.

\begin{tabular}{|c|c|c|c|}
\hline Type of Renewable Energy & Type of Logistics Company & Risk Factors & Type of Renewable Energy \\
\hline \multirow{3}{*}{ Biomass energy } & \multirow[b]{2}{*}{ Manufacturing company } & $\begin{array}{l}\text { Incorrect determination of fuel } \\
\text { consumption during assumed } \\
\text { technological operations. }\end{array}$ & $\begin{array}{l}\text { There is a probability of stopping the } \\
\text { production line. This also uses } \\
\text { conventional energy sources. }\end{array}$ \\
\hline & & High price volatility of raw material. & $\begin{array}{l}\text { The need to raise the price of the } \\
\text { manufactured product. Failure to } \\
\text { receive the assumed financial return on } \\
\text { a commercial transaction. }\end{array}$ \\
\hline & Warehouse company & $\begin{array}{l}\text { Risk of a limited amount of raw } \\
\text { material for drying. }\end{array}$ & $\begin{array}{l}\text { Growing biomass can be seen in many } \\
\text { regions as an opportunity for the } \\
\text { development of agriculture and can, at } \\
\text { the same time, reduce unemployment. } \\
\text { Construction of new storage facilities } \\
\text { for the storage of goods intended for } \\
\text { biomass energy. }\end{array}$ \\
\hline Type of Renewable Energy & Type of Logistics Company & Risk Factors & Type of Renewable Energy \\
\hline \multirow{10}{*}{ Wind energy } & \multirow{2}{*}{ Manufacturing company } & Limited production capacity. & $\begin{array}{l}\text { Supporting the enterprise with a } \\
\text { conventional energy source or } \\
\text { investing in two different sources of } \\
\text { renewable energy. }\end{array}$ \\
\hline & & Unstable delivery current. & $\begin{array}{l}\text { There is a need for reserve capacity. } \\
\text { Support of the enterprise with a } \\
\text { conventional energy source. }\end{array}$ \\
\hline & \multirow{2}{*}{ Warehouse company } & $\begin{array}{l}\text { Risk of not finding a suitable location } \\
\text { for a windmill in close proximity to } \\
\text { the facility. }\end{array}$ & $\begin{array}{l}\text { Building a windmill in an undeveloped } \\
\text { area. Choosing a different source of } \\
\text { renewable energy. }\end{array}$ \\
\hline & & $\begin{array}{l}\text { The risk of too much noise in logistics } \\
\text { and residential buildings. }\end{array}$ & $\begin{array}{l}\text { Conducting noise research before } \\
\text { starting the investment. }\end{array}$ \\
\hline & \multirow{6}{*}{ Logistics company } & \multicolumn{2}{|c|}{ Risk factors that may occur in any logistics company. } \\
\hline & & \multicolumn{2}{|l|}{ Risk of limited installation capacities. } \\
\hline & & \multicolumn{2}{|l|}{ Risk of financial investments. } \\
\hline & & \multicolumn{2}{|c|}{ Risk of weather influence on the operation and failure rate of the device. } \\
\hline & & \multicolumn{2}{|l|}{ Risk of corrosion of the structure. } \\
\hline & & \multicolumn{2}{|c|}{ Risk of an unstable government support policy. } \\
\hline
\end{tabular}

Source: Own study.

The table above shows the risk factors that may occur in logistics companies using renewable energy from solar, biomass, and wind energy. Risk factors have been classified in terms of belonging to a given type of logistics enterprise and appropriate mechanisms that can be used by the entity have been presented. The characterized control mechanisms show monitoring devices available on the market and elements that can be followed by logistics companies making a choice to invest in renewable energy sources and units already using an unconventional energy source.

\section{Diagram of the Risk-Related Decision-Making Process around Renewable Energy Sources}

Logistics management is a key element during production and distribution. This process consists of planning, organizing, and controlling the flow of energy, product, and raw material from the distributor to the consumer. It is already a very important element at the investment stage $[27,28]$.

One of the goals of logistics is efficiency. This element consists of planning and controlling the flow of raw materials, finished products, and information, while minimizing costs and impact on the natural environment [29].

Over the last few years, there has been a dynamic increase in investments in the field of obtaining energy from renewable sources, which is why it is so important to present risk factors that may occur in a logistics company that invests in and uses an unconventional source of energy. 
The selection of any given type of renewable energy source requires the identification and analysis of the probability of the occurrence of risk factors. Proper risk management should be started at the stage of investment in an unconventional energy source and then cyclically repeated during the use of that energy source.

The key element is the development by the logistics company of the diagram of the risk-related decision-making process around renewable energy sources, in order to reduce the likelihood of a risk factor for a particular renewable energy source.

Based on the research carried out in enterprises that are in the process of investing in renewable energy sources or planning such an investment in the near future and the analysis of many cases described in the literature [12,18,29-34] the authors developed a diagram of the decision-making process of logistics companies around renewable energy sources. The starting point was the assessment of their effectiveness in terms of RES risk factors. The authors put forward the thesis that the implementation of the procedure for selecting an appropriate renewable energy source by logistics entities and the implementation of a risk management element has a significant positive impact on the optimal selection of a renewable energy source by an enterprise.

As a result of the research, a diagram of the decision-making process of logistics companies around renewable energy sources was created, presented in Figure 1.

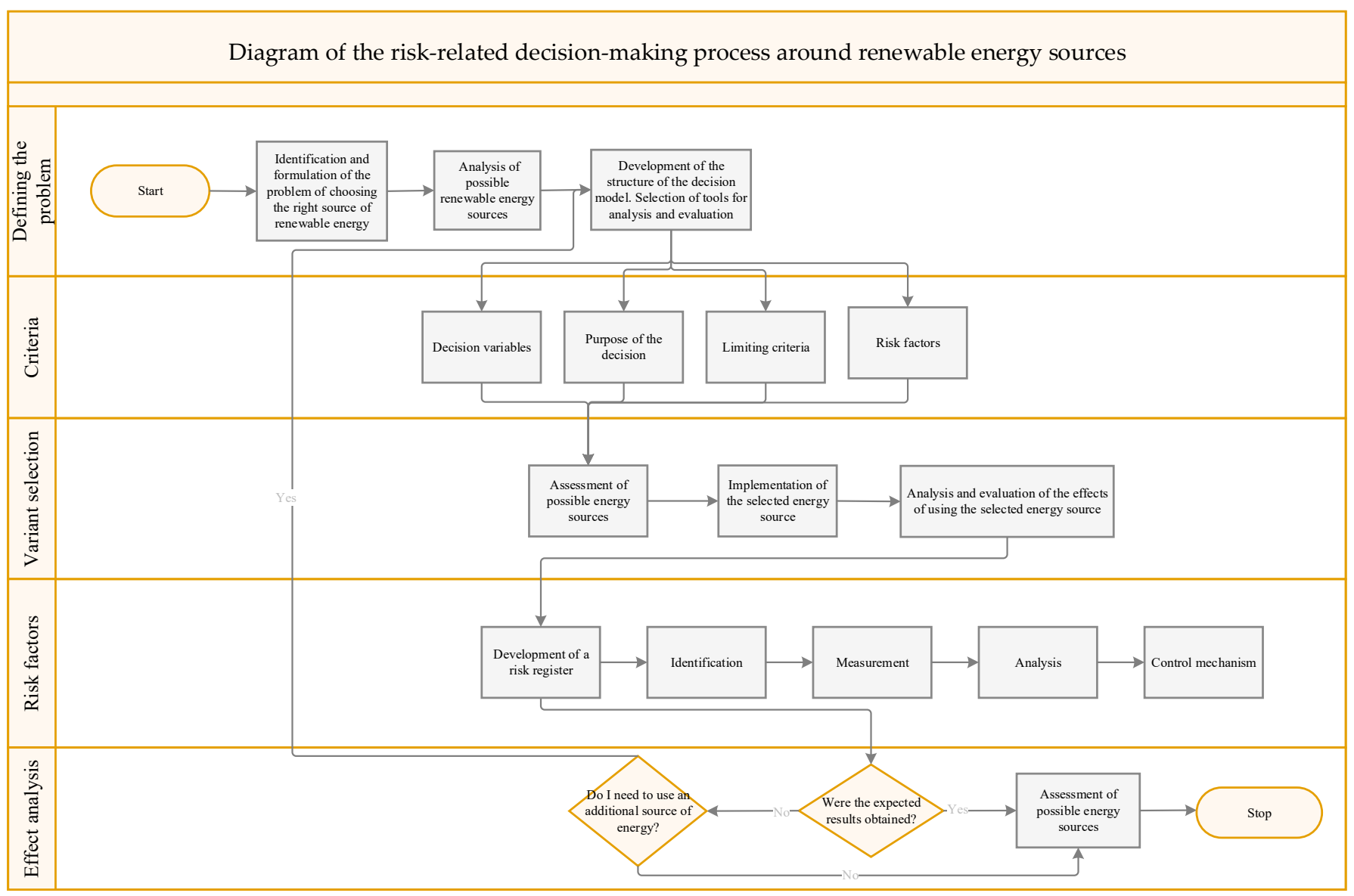

Figure 1. Diagram of the risk-related decision-making process around renewable energy sources. Source: Own study.

The diagram above shows the process of selecting an appropriate renewable energy source while managing risk factors. The block diagram has been divided into five stages:

(1) Defining the problem-defining the problem of selecting an appropriate renewable energy source with an indication of the availability of a particular energy source. 
(2) Criteria-it is necessary to define possible risk factors during the selection of an appropriate energy source and the use itself. Before making a decision, a logistics company needs to define the goal and the criteria for achieving it.

(3) Variant selection-implementation of the selected energy source. Analysis and evaluation of the usability of a given energy source.

(4) Risk factors-developing a risk register as the basic element of risk management, which consists of four elements: identification, measurement, analysis, and control mechanism.

(5) Effect analysis-final assessment of the energy sources used, consisting of two conditional operations aimed at controlling the consumption and the affectivity of the implemented energy sources. For the possibility of using new or developing alreadyused renewable energy sources.

Investments by logistics entities in renewable energy sources involve appropriate financial outlays. Although this involves an initially high financial investment, after a certain period of time, it should bring a financial benefit to the entity. However, the most important element is to maintain the continuity of logistics activities performed by a given entity, where the key element is to prevent a lack of access to energy. The procedures developed by logistics entities should be utilitarian. Enterprises should systematically introduce changes to their procedures, taking into account the amount of energy consumed over a period of time.

Risk analysis of renewable energy sources is an important element in assessing their effectiveness. Implementing the procedure of selecting an appropriate renewable energy source by logistics entities, with simultaneous continuous management of risk factors, significantly influences the best decision to invest in renewable energy sources for entities using renewable energy sources.

\section{Conclusions}

In recent years, there has been a dynamic growth of enterprises using and investing in energy from renewable sources. Increasing competitiveness, additions from the state, environmental protection, the behavior of consumers and potential customers, for whom the pro-ecological behavior of enterprises has an impact on the choice of decisions, mean that this trend will certainly continue.

Making a decision to invest in renewable energy sources requires a detailed analysis of each type of unconventional energy source and the identification and assessment of possible risk factors. This paper indicates control mechanisms which aim to show logistics companies possible actions limiting the probability of the occurrence of any given risk factor.

In this work, a diagram of the risk-related decision-making process around renewable energy sources was developed, the purpose of which is to select the appropriate type of renewable energy source, while managing risk factors. The model is divided into four areas, which indicate the phased implementation and evaluation of the results obtained after the implementation of the renewable energy source. Risk is an inherent element of every logistics company, which is why it is so important to manage it. The identification and analysis of risk factors is a basic element of disruption management, and the developed model for selecting an appropriate renewable energy source will also reduce the likelihood of risk factors.

Risk analysis of renewable energy sources is an important element in assessing their efficiency and provides the opportunity to make the right decision when investing in and using renewable energy source.

The RES risk analysis is an important element in assessing the effectiveness of RES. The procedure developed for enterprises is intended to be utilitarian. Implementing the procedure of selecting an appropriate renewable energy source by logistic entities, with simultaneous continuous management of risk factors, significantly influences the best 
decision to invest in renewable energy sources and is also useful for companies already using renewable energy sources.

Author Contributions: Conceptualization, E.K. and J.G.; methodology, E.K.; formal analysis, E.K. and J.G.; investigation, E.K. and J.G.; resources, E.K. and J.G.; data curation, E.K.; writing-preparation of an original project, J.G.; visualization, J.G.; supervision, E.K.; obtaining financing, E.K. All authors have read and agreed to the published version of the manuscript.

Funding: This research received no external funding.

Institutional Review Board Statement: Not applicable.

Informed Consent Statement: Not applicable.

Data Availability Statement: Not applicable.

Conflicts of Interest: The authors declare no conflict of interest.

\section{References}

1. Górniak, J.; Krajewski, P. Ekotaksówki Jako Narzędzie Zielonej Logistyki (Ecotaxis as a Green Logistics Tool); Zeszyty Naukowe Politechniki Poznańskiej, Organizacja i Zarządzanie, Politechnika Poznańska: Poznań, Poland, 2013.

2. Szołtysek, J. Logistyka Zwrotna (Reverse Logistics); Biblioteka Logistyka: Poznań, Poland, 2009.

3. Ministerstwo Środowiska. Strategiczny Plan Adaptacji Dla Sektorów i Obszarów Wrażliwych na Zmiany Klimatu do Roku 2020 z Perspektywa do Roku 2030 (Strategic Adaptation Plan for Sectors and Areas Sensitive to Climate Change by 2020 with a Perspective by 2030); Ministerstwo Środowiska: Warszawa, Poland, 2013.

4. Dubel, A. Analiza Cech Ryzyka Powodzi Pod Katem Projektowania Instrumentów Transferu Tego Ryzyka (Analysis of Flood Risk Features in Terms of Designing the Risk Transfer Instruments); Ekonomia i Środowisko: Białystok, Poland, 2014.

5. Dubel, A. Efektywna Logistyka Jako Narzędzie Adaptacji do Zmian Klimatycznych (Effective Logistics as a Tool of Adaptation to Climate Change); Logistyka: Warszawa, Poland, 2015.

6. Kondratowicz-Pozorska, J. Rola Państwa Wedtug Ekonomii Ekologii, Środowiska i Zrównoważonego Rozwoju (The Role of the State According to the Economics of Ecology, Environment and Sustainable Development); Uniwersytet Szczeciński: Szczecin, Poland, 2015.

7. Zwierzchowska, M. Odnawialne źródła energii a zielona gospodarka w Polsce (Renewable energy sources and the green economy in Poland). Rynek-Społeczeństwo-Kult. 2018, 4, 80-86.

8. Grudziński, A.; Sulich, A. Zielone Miejsca Pracy_Element Przewagi Konkurencyjnej Przedsiębiorstw Sektora Odnawialnych Źródeł Energii (Green Jobs-An Element of the Competitive Advantage of Enterprises in the Renewable Energy Secto); Marketing i Rynek: Warszawa, Poland, 2018.

9. Piekut, M. The Consumption of Renewable Energy Sources (RES) by the European Union Households between 2004 and 2019. Energies 2021, 14, 5560. [CrossRef]

10. Borgosz-Koczwara, M.; Herlender, K. Bezpieczeństwo Energetyczne, a Rozwój Odnawialnych Źródeł Energii (Energy Security and the Development of Renewable Energy Sources); Oficyna Wydawnicza Energia: Wrocław, Poland, 2008.

11. Kosiński, E.; Trupkiewicz, M. Gmina Jako Podmiot Systemu Wspierania Wytwarzania Energii Elektrycznej z Odnawialnych Źródłe Energii. Ruch Prawniczy, Ekonomiczny i Socjologiczny (The Commune as an Entity of the Support System for the Production of Electricity from Renewable Energy Sources. Legal, Economic and Sociological Movement); Uniwersytet im. Adama Mickiewicza: Poznaniu, Poland, 2016.

12. Brodny, J.; Tutak, M.; Saki, S.A. Forecasting the Structure of Energy Production from Renewable Energy Sources and Biofuels in Poland. Energies 2020, 13, 2539. [CrossRef]

13. Mirowski, T. Wybrane problemy związane z wykorzystaniem odnawialnych źródeł energii w Polsce (Selected problems related to the use of renewable energy sources in Poland). Zesz. Nauk. Inst. Gospod. Surowcami Miner. I Energia PAN 2017, 98, 5-14.

14. Standar, A.; Kozera, A.; Satoła, Ł. The Importance of Local Investments Co-Financed by the European Union in the Field of Renewable Energy Sources in Rural Areas of Poland. Energies 2021, 14, 450. [CrossRef]

15. Anagnostopoulos, T.; Kyriakopoulos, G.L.; Ntanos, S.; Gkika, E.; Asonitou, S. Intelligent Predictive Analytics for Sustainable Business Investment in Renewable Energy Sources. Sustainability 2020, 12, 2817. [CrossRef]

16. Bajor, M. Innowacyjne Metody Pozyskiwania Energii z Odnawialnych Źródeł Energii (Innovative Methods of Obtaining Energy from Renewable Energy Sources); Zeszyty Naukowe; Organizacja i Zarządzanie, Politechnika Ślasska: Zabrze, Poland, 2017.

17. Frączek, P.; Pilarski, K.; Tyrpa, P. Odnawialne Źródła Energii (Renewable Energy Sources). 2008. Available online: http: / / energieodnawialne.pl/download/pl/odnawialne_zrodla_energii.pdf (accessed on 7 July 2021).

18. Golovanov, N.; Lazaroiu, G.C.; Roscia, M.; Zaninelli, D. Power Quality Assessment in Small Scale Renewable Energy Sources Supplying Distribution Systems. Energies 2013, 6, 634-645. [CrossRef]

19. Niedzółka, I.; Szpryngiel, M. Możliwości wykrozystania biomasy na cele energetyczne (Possibilities of using biomass for energy purposes). Agric. Eng. 2014, 18, 155-164. 
20. Li, Q.; Cherian, J.; Shabbir, M.S.; Sial, M.S.; Li, J.; Mester, J.; Badulescu, A. Exploring the Relationship between Renewable Energy Sources and Economic Growth. The Case of SAARC Countries. Energies 2021, 14, 520. [CrossRef]

21. Sobczak, P.; Bukowski, L. Wspótczesne Problemy Logistyki Stosowanej (Contemporary Problems of Applied Logistics); WSB Dąbrowa Górnicza: Dąbrowa Górnicza, Poland, 2017.

22. Krajewska, R.; Łukasik, Z. Modelowanie wybranych procesów logistycznych w elektrociepłowni (Modeling of selected logistic processes in a heat and power plant). In Autobusy: Technika, Eksploatacja, Systemy Transportowe; Instytut Naukowo-Wydawniczy "SPATIUM" sp. z o.o.: Radom, Poland, 2017; Volume 18, pp. 1529-1534.

23. Ziborács, H.; Baranyai, N.H.; Vincze, A.; Zentkó, L.; Birkner, Z.; Máté, K.; Pintér, G. Intermittent Renewable Energy Sources: The Role of Energy Storage in the European Power System of 2040. Electronics 2019, 8, 729. [CrossRef]

24. Kulińska, E. Aksjologiczny Wymiar Zarzadzania Ryzykiem Procesów Logistycznych. Modele i Eksperymenty Ekonomiczne (Axiological Dimension of Risk Management in Logistics Processes. Economic Models and Experiments); Oficyna Wydawnicza Politechniki Opolskiej: Opole, Poland, 2011.

25. Kasiewicz, S. Ryzyko Inwestowania w Polskim Sektorze Energetyki Odnawialnej (The Risk of Investing in the Polish Renewable Energy Sector); CeDeWu: Warszawa, Poland, 2012.

26. Michalak, J. Ryzyko w Projektach Inwestycyjnych Energetyki Odnawialnej (Risk in Renewable Energy Investment Projects). Pozn. Univ. Technol. Acad. J. Electr. Eng. 2014, 79, 105-111.

27. Suchon, A. Selected renewable energy legal issues in the context of logistics management. J. Agribus. Rural Dev. 2015, 2, 313-321. [CrossRef]

28. Świerczek, A. Koncepcja Zarządzania Procesami Logistycznymi w Przedsiębiorstwie (The Concept of Managing Logistic Processes in an Enterprise); Zeszyty Naukowe WSZOP: Katowice, Poland, 2006.

29. European Commission. White Paper: Adapting to Climate Change: Towards a European Framework for Action; European Commission COM: Brussels, Belgium, 2009; Volume 147.

30. Bojar, W.; Rostek, K.; Knopik, L. Systemy Wspomagania Decyzji (Decision Support Systems); Polskie Wydawnictwo Ekonomiczne: Warszawa, Poland, 2014.

31. Gaska, K. Modelowanie Zintegrowanych Systemów Gospodarki Odpadami z Wykorzystaniem Metodologii Zorientowanej Obiektowo (Modeling of Integrated Waste Management Systems Using Object-Oriented Methodology); Wydawnictwo Politechniki Ślaskiej: Gliwice, Poland, 2012.

32. Górniak-Zimroz, J. Wykorzystanie Systemów Wspomagania Decyzji w Gospodarce Odpadami (The Use of Decision Support Systems in Waste Management); Prace Naukowe Instytutu Górnictwa Politechniki Wrocławskiej; Studia i Materiały: Wrocław, Poland, 2007; Volume 118, pp. 23-41.

33. Hayajneh, H.S.; Zhang, X. Logistics Design for Mobile Battery Energy Storage Systems. Energies 2020, 13, 1157. [CrossRef]

34. Pires, A.; Martinho, G.; Chang, N.-B. Solid waste management in European countries: A review of systems analysis techniques. J. Environ. Manag. 2011, 92, 1033-1050. [CrossRef] [PubMed] 